\title{
Ecology of Meiobenthos Inhabiting the Local Biotopes of Gas Seeps in Coastal Waters of Crimea: Taxonomic Composition and Distribution in Bottom Sediments
}

\author{
Ekaterina A. Ivanova* and Maksim B. Gulin \\ A.O. Kovalevsky Institute of Biology \\ of the Southern Seas of RAS \\ Sevastopol, Russian Federation
}

Received 02.11.2019, received in revised form 24.11.2020, accepted 14.12.2020

\begin{abstract}
The present study reports results of investigation of meiobenthos from shallow-water gas seeps of Cape Tarkhankut (North-Western Crimea). The meiobenthic communities at the gas seeps have been found to be suppressed and less abundant than the zoobenthos in the surrounding seabed substrates. The density peaks of seep meiofauna are confined to the upper 0-3 cm layer, in contrast to the surrounding sands, where much more abundant meiofauna is located deeper in the sediment layer. Dominant and subdominant meiobenthic taxa are Nematoda, Foraminifera (Allogromiida), and Polychaeta. It is highly likely that among the meiofauna that was found in the seep marine sediments, there was a significant percentage of dead bodies from the surface layers, trapped inside the microbial mat because of the high growth rate of the bacterial substrate. Sulfidic seep sediments reduce the concentration of oxygen within the $1.5 \mathrm{~m}$ near-bottom layer. Seep sediments form specific "extreme" biotopes, where the environment rich in organic matter is combined with high concentrations of hydrogen sulfide and lack (or complete absence) of oxygen.
\end{abstract}

Keywords: meiobenthos, shallow gas seeps, hypoxia, hydrogen sulfide contamination, the Black Sea.

(C) Siberian Federal University. All rights reserved

This work is licensed under a Creative Commons Attribution-NonCommercial 4.0 International License (CC BY-NC 4.0).

* Corresponding author E-mail address: katya.iva@mail.ru ORCID: 0000-0002-3644-4362 (Gulin M.) 


\title{
Экология мейобентоса в локальных биотопах
}

газовых сипов прибрежной акватории Крыма:

таксономический состав

и распределение в толще осадков

\author{
Е.А. Иванова, М.Б. Гулин \\ Институт биологии южных морей \\ им. А.О. Ковалевского РАН \\ Российская Федерация, Севастополь
}

\begin{abstract}
Аннотация. Представлены результаты исследований мейобентоса из мелководных газовых сипов мыса Тарханкут (Северо-Западный Крым). Показано, что мейобентосные сообщества сипов угнетены, что отражается в снижении их численности в сравнении с окружающими их донными субстратами. Пики численности мейофауны сипов приурочены к верхнему слою (0-3 см) микробного мата в отличие от окружающих песчаных грунтов, где гораздо более обильная бентосная фауна проникает глубже в донные осадки. Доминирующими и субдоминирующими таксонами мейобентоса являются Nematoda, Foraminifera (Allogromiida) и Polychaeta. Вероятно, значительная доля мейофауны, обнаруженной в сипах, - это погибшие особи из поверхностных слоев, оказавшиеся в толще микробиального мата вследствие высокой скорости нарастания бактериального субстрата. Сульфидные сиповые осадки снижают концентрацию кислорода в придонном слое водной толщи на расстоянии до 1,5 м от поверхности дна. В сиповых осадках формируется «экстремальный» биотоп, где обилие органических веществ сочетается с присутствием сероводорода в критической для организмов концентрации и недостатком (либо полным отсутствием) кислорода.
\end{abstract}

Ключевые слова: мейобентос, мелководные газовые сипы, гипоксия, сероводородное заражение, Черное море.

Цитирование: Иванова, Е.А. Экология мейобентоса в локальных биотопах газовых сипов прибрежной акватории Крыма: таксономический состав и распределение в толще осадков / Е.А. Иванова, М.Б. Гулин // Журн. Сиб. федер. ун-та. Биология, 2020. 13(4). C. 410-423. DOI: 10.17516/1997-1389-0337

\section{Введение}

Дегазация донных осадков в Мировом океане имеет почти повсеместный характер (Skarke et al., 2014). Для биогеохимической трансформации захороненного в осадочных породах органического вещества и газообразования (в основном метана) необходимы лишь условия аноксии и низкого содержания сульфатов в поровой воде. Вместе с тем рас- сеянные спорадические газовые выбросы из морского дна не способны оказывать какоелибо существенное влияние на экологию придонного слоя и водной толщи в целом. Значительный интерес представляют лишь те локальные участки дна, в которых эмиссия газов проявляется как активный и долговременный фактор (Молисмология Черного моря, 1992). 
Ранее в результате целенаправленных поисковых работ было установлено, что в прибрежной зоне южного сектора полуострова Тарханкут, составляющего северо-западную часть Крыма, располагается поле активных выделений газообразного метана из донных отложений (Gulin, 2004). Первые наблюдения указанных природных объектов - холодных газовых сипов (cold gas seeps) - Тарханкута были сделаны летом 1980 г., что позволяет отнести данную находку к одной из первых в целом для Мирового океана (Гулин и др., 2010).

Макрофауна специфических сиповых биотопов в крымском прибрежье изучалась в районе мыса Тарханкут в 2009 г. (Гулин и др., 2010). В нашем исследовании внимание акцентируется на мейобентосе - экологической группе донных животных, размер тела которых не превышает 1 мм. Помимо исследований в настоящей работе, изучение мейобентоса прибрежных метановых сипов мыса Тарханкут проводилось в кооперации с другими авторами (Sergeeva et al., 2005; Сергеева и др., 2006; Колесникова, Сергеева, 2011), а также в Двуякорной бухте (Восточный Крым) в 2013 г. (Иванова, 2017). Согласно полученным данным, сообщества морского мейобентоса в местах выхода газов со дна находятся в более угнетенном состоянии, чем мейобентос окружающих чистых песков. Таксономический состав поселений донной фауны также различен.

Целью данной работы является определение особенностей таксономического состава и пространственного распределения мейофауны в толще донных осадков, формирующихся непосредственно вблизи мест высачиваний газов на мелководных участках черноморского шельфа. Также рассматриваются вопросы формирования экстремальных условий существования биоты в осадках газовых сипов.
Целесообразность отдельного рассмотрения экологии таких природных объектов морской бентали, как газовыделения из морского дна на малых глубинах, обусловлена тем, что прибрежные районы с расположенными в них газовыми сипами наиболее подвержены неблагоприятным гидрометеорологическим воздействиям (шторма́, ливневые сбросы взвесей с береговых склонов и проч.), чего не наблюдается в глубоководных районах моря.

\section{Материалы и методы}

Сборы проб донных осадков проводились в районе мыса Тарханкут (рис. 1) в период 2004-2017 гг. между с. Марьино и с. Окуневка, непосредственно в сульфуреттах мелководных газовых сипов и в окружающих осадках чистого песка (фон). В данной местности находится локальное поле высачиваний пузырьковых струй газов со дна, преимущественно метана (Gulin, 2004; Tarnovetskii et al., 2018). В масштабе всей северо-западной части Черного моря этот участок является фрагментом пояса газовых сипов, пролегающего от главного поля газовыделений в Днепровском каньоне вдоль Каламитской складчатой структуры и разделяющего Каркинитскую и Альминскую депрессии.

В непосредственной близости от береговой черты был найден локальный участок дна с многочисленными струйными газовыделениями из осадочных пород. Эти газовые сипы имели различную интенсивность, к тому же значительно варьирующую в разные периоды наблюдений. В целом, площадка указанного скопления сипов имеет форму вытянутого эллипса, начинающегося примерно в 100 м от берега и залегающего почти параллельно ему в направлении восток-юговосток. Наибольшая протяженность поля сипов составляет около 200 м, а ширина - до 


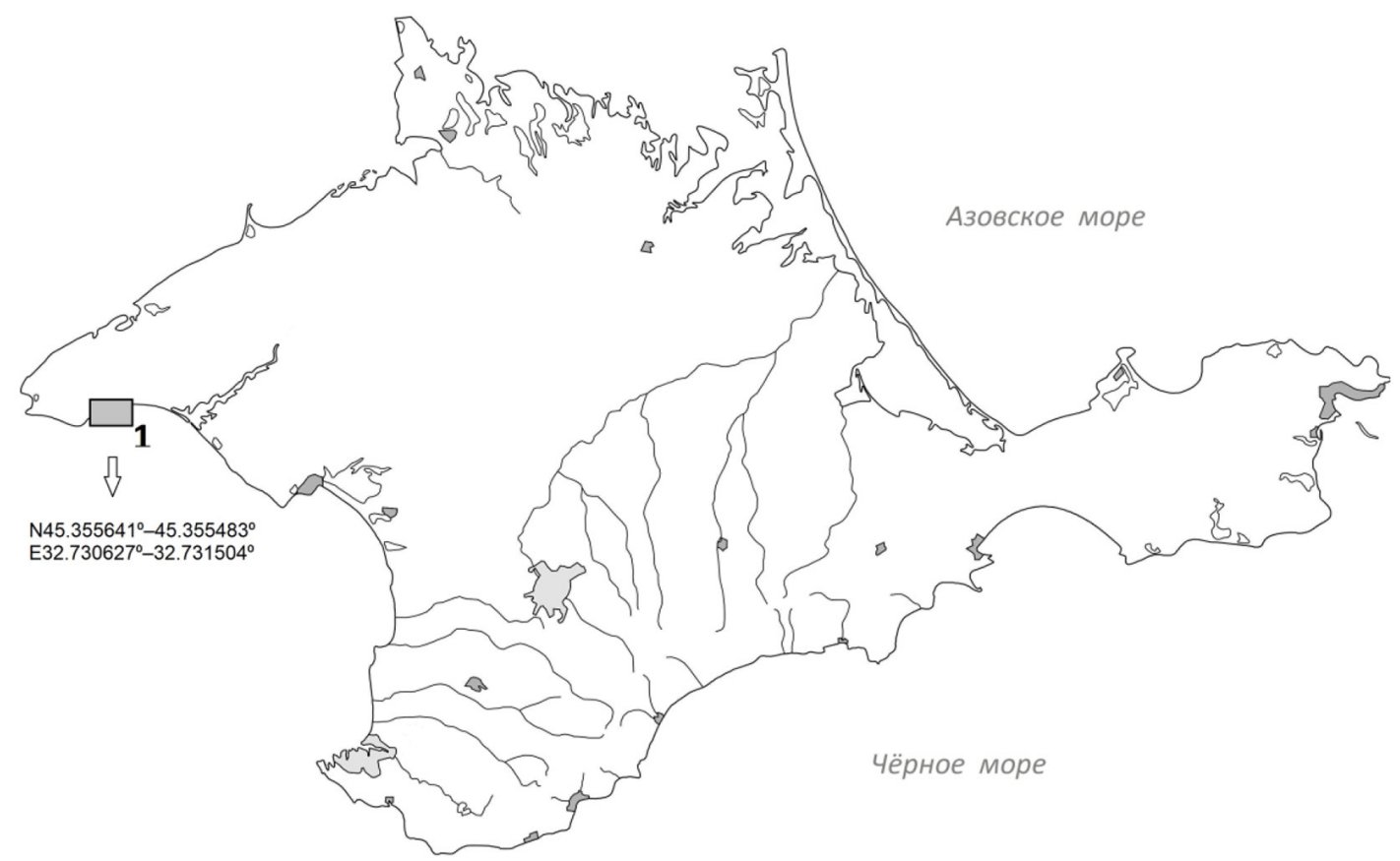

Рис. 1. Район исследований (1) на мысе Тарханкут (Северо-Западный Крым) в 2004-2017 гг.

Fig. 1. Study area (1) at Cape Tarkhankut (North-Western Crimea) during 2004-2017

25 м. Участок дна в пределах данного поля, характеризующийся наиболее активным газопроявлением, располагается на глубинах 3,5-6,3 м, координаты точек его наибольшего протяжения: $45.355641^{\circ}$ с.ш., $32.730627^{\circ}$ в.д. $45.355483^{\circ}$ с.ш., $32.731504^{\circ}$ в.д. На этой площадке и производили отбор проб, измерения параметров среды и визуальные наблюдения.

Сиповые донные отложения отличались от фоновых песков наличием черного слоя бактериальных матов, сильным запахом сероводорода и периодическими выбросами пузырьков газа разной интенсивности. В 2004 г. интенсивность потока газообразного метана из дна составляла 2 л/ $\mathrm{M}^{2} \cdot$ сут в пересчете на так называемое нормальное атмосферное давление (Gulin, 2004).

Сопряженный с полем сипов участок дна для фоновых исследований представлял собой песчаную поляну типичных нормоксических осадков, тянущуюся параллельно по- лосе сиповых осадков, с координатами центра $45.356009^{\circ}$ с.ш., $32.730134^{\circ}$ в.д.

Даты и глубины отбора проб и проведения измерений за весь период исследований представлены в табл. 1.

В 2004-2006 гг. отбор проб грунта для мейобентосных исследований в различных местах высачивания газа проводили водолазы с использованием пластиковой трубки площадью 37,4 см², а в 2014-2017 гг. - пластиковым шприцем диаметром 40 мм. Пробы фиксировали 76\%-ным раствором этанола, в 2014 г. - 4\%-ным раствором формалина. Затем образцы осадка промывали через сито с диаметром ячеи $30 \mu \mathrm{m}$, окрашивали красителем «Бенгальский розовый». Для сравнительного анализа численности мейобентоса и структуры его сообществ использованы данные за 2004 г. из предыдущей нашей работы (Sergeeva et al., 2005). В 2014 г. для послойного изучения распределения мейобентоса в толще осадка отбор проб произведен пластиковым 
Таблица 1. Даты и глубины отбора проб и характеристика донных осадков в местах отбора (ОВП окислительно-восстановительный потенциал в слое 0-5 см, ОВ - содержание общего органического вещества в осадках (среднее $\pm \mathrm{SE}, \mathrm{n}=3)$ )

Table 1. Sampling dates and depths and characteristics of bottom sediments at the sampling sites (OBП - redox potential in the $0-5 \mathrm{~cm}$ layer, $\mathrm{mV}$; $\mathrm{OB}$ - total organic matter content in sediments, $\mathrm{mg} / \mathrm{g} \mathrm{dw}(\mathrm{mean} \pm \mathrm{SE}, \mathrm{n}=3)$ )

\begin{tabular}{c|c|c|c|c}
\hline $\begin{array}{c}\text { Тип } \\
\text { местообитания }\end{array}$ & Дата & Глубина, м & ОВП, мВ & \begin{tabular}{c} 
ОВ, мГ $/$ сухого вещества \\
\hline Сип 1
\end{tabular} Сентябрь 2004 \\
Сип 2 & Сентябрь 2004 & 4,8 & - & - \\
Сип & Сентябрь 2006 & 6,8 & - & $336,10 \pm 5,34$ \\
Сип & Август 2008 & 3,5 & -385 & $280,56 \pm 13,03$ \\
Сип & Сентябрь 2009 & 3,5 & - & $247,63 \pm 3,31$ \\
Сип & Август 2010 & 3,5 & - & $151,90 \pm 3,20$ \\
Сип & Сентябрь 2014 & 3,5 & -281 & - \\
Сип & Май 2016 & 6,3 & - & - \\
Сип & Сентябрь 2017 & 3,5 & - & - \\
Фон & Сентябрь 2004 & 4,8 & - & - \\
Фон & Сентябрь 2006 & 6,0 & -178 & $26,26 \pm 1,37$ \\
Фон & Август 2008 & 3,5 & - & $36,40 \pm 3,31$ \\
Фон & Сентябрь 2009 & 3,5 & - & $56,67 \pm 3,33$ \\
Фон & Сентябрь 2014 & 3,5 & - & - \\
Фон & Май 2016 & 6,0 & - \\
\hline
\end{tabular}

Примечание: вариации по глубине отбора проб донных осадков обусловлены уклоном дна в пределах сульфуретты сипа, а также периодическим наносом или, наоборот, смывом песчаных отложений при сильных штормах.

шприцем диаметром 40 мм с послойным делением грунта по 1 см до глубины 12 см. Извлечение из грунта и идентификацию организмов проводили с помощью бинокулярного микроскопа. Одновременно отбирали пробы грунта для измерения содержания органического вещества по (Hewitt, Mudge, 2004) методом учета потери веса при прокаливании.

Для определения окислительно-восстановительных условий в осадках тарханкутских сипов в местах отбора биологических образцов производили измерения редокс-потенциала (ОВП или Еh, мВ). Использовалась стандартная потенциометрическая аппаратура: универсальный иономер РН150М и ЭВ-74 (ГЗИП, Беларусь) в комплекте с платиновым измерительным электродом (Corning Glass Works, Корнинг - Нью-Йорк, США) и встро- енным в него хлорсеребряным электродом сравнения либо мультиметр «Hach-Sension-1» (Hach, США). Следует отметить, что редокспотенциал в микробных матах измеряли сразу же после доставки проб на берег, чтобы сохранить свойства осадков, близкие к таковым in situ.

Измерения концентрации растворенного кислорода и температуры в водной толще и непосредственно на границе “вода - донные осадки" осуществляли in situ с применением оксиметра HQ40d (Hach, CША), снабженного погружным блоком сенсоров на кабель-тросе - оптодом оксиметра и термистором.

\section{Результаты и обсуждение}

Окислительно-восстановительный потенциал (ОВП) в слое осадка 0-5 см достигал 
значительных отрицательных величин, что свидетельствует о формировании кислороддефицитных условий среды (табл. 1).

Сравнительная оценка численности крупных таксонов в период 2004-2017 гг. показывает, что мейобентосные сообщества сипов заметно угнетены в сравнении с поселениями зообентоса в прилегающих донных субстратах (табл. 2, 3). Общая численность мейофауны сиповых осадков на Тарханкуте достоверно ниже по сравнению с окружающими песками, не подвергающимися процессам микробиологического разложения метана с образованием токсичных условий среды - гипоксии и присутствием сероводорода. В соответствии с данными табл. 2 средняя плотность поселений в сипах равна $865 \pm 295$, тогда как в фоновых точках она составляла $12221 \pm 2744$ экз/0,01 м² (экз/0,01 м², \pm стандартная ошибка среднего).

Анализ таксономического состава сообществ мейобентоса установил, что доминирующими группами в сентябре 2004 г. в сипе являлись круглые черви - нематоды, а на фоновых участках дна - нематоды и гарпактикоиды (субдоминанты). В сентябре 2006 г. в осадках сипов также доминировали нематоды, однако в меньшей степени. Для фоновых донных отложений оказалось характерным преобладание многощетинковых червей - полихет. В 2014 г. на контрольных станциях в сообществах преобладали нематоды, тогда

Таблица 2. Встречаемость (D, \%) и численность $\left(\mathrm{N}\right.$, экз $\left./ 0,01 \mathrm{M}^{2}\right)$ таксонов сообщества мейобентоса в слое грунта 0-5 см в 2004 и 2006 гг.

Table 2. Percentage (D, \%) and density $\left(\mathrm{N}\right.$, ind./0.01 $\left.\mathrm{m}^{2}\right)$ of taxa in meiobenthic communities in the sediment $0-5 \mathrm{~cm}$ layer in 2004 and 2006

\begin{tabular}{|c|c|c|c|c|c|c|c|c|c|c|}
\hline \multirow{3}{*}{ Таксон } & \multicolumn{6}{|c|}{ Сентябрь 2004} & \multicolumn{4}{|c|}{ Сентябрь 2006} \\
\hline & Сип1* & фон ${ }^{*}$ & Сип1* & $\phi \mathrm{OH}^{*}$ & Сип2 & Сип2 & сип & фон & сип & фон \\
\hline & \multicolumn{2}{|c|}{$\mathrm{D}$} & \multicolumn{2}{|c|}{$\mathrm{N}$} & $\mathrm{D}$ & $\mathrm{N}$ & \multicolumn{2}{|c|}{$\mathrm{D}$} & \multicolumn{2}{|c|}{$\mathrm{N}$} \\
\hline Acarina & - & - & - & - & - & - & 3,4 & 0,3 & 31 & 13 \\
\hline Amphipoda & 1,4 & - & 5 & - & - & - & - & - & - & - \\
\hline Bivalvia juv & 0,7 & 0,1 & 3 & 19 & 0,8 & 3 & 20,7 & - & 192 & - \\
\hline Ciliata & - & 1,5 & - & 187 & - & - & - & - & - & - \\
\hline Decapoda juv. & - & 0,2 & - & 21 & - & - & - & - & - & - \\
\hline Foraminifera & 0,7 & 1,5 & 3 & 192 & 0,8 & 3 & 10,3 & 23,8 & 96 & 1069 \\
\hline Gastropoda & - & 0,1 & - & 11 & - & - & - & - & - & - \\
\hline Harpacticoida & 2,9 & 31,1 & 11 & 3952 & 3,0 & 11 & 10,3 & 8,8 & 96 & 393 \\
\hline Nematoda & 87,8 & 64 & 326 & 8133 & 91,9 & 326 & 45 & 23,1 & 419 & 1037 \\
\hline Nemertini & 2,2 & - & 8 & - & - & - & - & - & - & - \\
\hline Oligochaeta & - & 0,1 & - & 13 & - & - & - & - & - & - \\
\hline Ostracoda & 0,7 & - & 3 & - & - & - & - & 0,3 & - & 16 \\
\hline Polychaeta & 3,6 & 0,8 & 13 & 96 & 3,8 & 13 & - & 43,6 & - & 1955 \\
\hline Tardigrada & - & - & - & - & - & - & 10,3 & - & 96 & - \\
\hline Turbellaria & - & 0,6 & - & 80 & - & - & - & - & - & - \\
\hline Всего & 100 & 100 & 371 & 12704 & 100 & 355 & 100 & 100 & 931 & 4482 \\
\hline
\end{tabular}

Примечание: жирным шрифтом выделены доминанты и субдоминанты мейобентосных сообществ; * данные из нашей работы (Sergeeva et al., 2005). 
Таблица 3. Встречаемость $(\mathrm{D}, \%)$ и численность $\left(\mathrm{N}\right.$, экз $\left./ 0,01 \mathrm{M}^{2}\right)$ таксонов сообществ мейобентоса в слое грунта 0-5 см в 2014-2017 гг.

Table 3. Percentage (D, \%) and density $\left(\mathrm{N}\right.$, ind./0.01 $\left.\mathrm{m}^{2}\right)$ of taxa in meiobenthic communities in the sediment $0-5 \mathrm{~cm}$ layer in 2014-2017

\begin{tabular}{|c|c|c|c|c|c|c|c|c|c|c|}
\hline \multirow{3}{*}{ Таксон } & \multicolumn{4}{|c|}{ Сентябрь 2014} & \multicolumn{4}{|c|}{ Май 2016} & \multicolumn{2}{|c|}{ Сентябрь 2017} \\
\hline & сип* & фон & сип* & фон & сип & фон & сип & фон & сип & сип \\
\hline & \multicolumn{2}{|c|}{$\mathrm{D}$} & \multicolumn{2}{|c|}{$\mathrm{N}$} & \multicolumn{2}{|c|}{$\mathrm{D}$} & \multicolumn{2}{|c|}{$\mathrm{N}$} & $\mathrm{D}$ & $\mathrm{N}$ \\
\hline Acarina & 12 & 0,05 & 68 & 8 & 2 & - & 42 & - & 8 & 52 \\
\hline Bivalvia juv. & 1 & - & 8 & - & 2 & 0,7 & 37 & 102 & - & - \\
\hline Ciliata & 13 & 7,6 & 78 & 1309 & - & 0,8 & - & 116 & 35 & 234 \\
\hline Cirripedia juv & 1 & - & 8 & - & - & - & - & - & 2 & 15,6 \\
\hline Decapoda juv. & - & 0,6 & - & 100 & - & 0,6 & 9 & 92 & - & - \\
\hline Foraminifera & 24 & 0,7 & 143 & 115 & 63 & 8,2 & 1428 & 1192 & 4 & 26 \\
\hline Gastropoda & - & - & - & - & - & - & 9 & - & - & - \\
\hline Gromia & - & - & - & - & - & - & - & & 1 & 5,2 \\
\hline Harpacticoida & 5 & 7,9 & 32 & 1365 & 3 & 31,3 & 74 & 4523 & 22 & 145,6 \\
\hline Isopoda & - & - & - & - & - & 0,2 & - & 32 & - & - \\
\hline Nematoda & 6 & 78,7 & 34 & 13576 & 28 & 45 & 647 & 6500 & 8 & 52 \\
\hline Nemertini & - & 1,1 & - & 191 & - & - & - & - & - & - \\
\hline Oligochaeta & - & 1,5 & - & 263 & - & - & - & - & - & - \\
\hline Ostracoda & 3 & 0,1 & 16 & 12 & 1 & 8,3 & 28 & 1201 & - & - \\
\hline Polychaeta & 34 & 1,8 & 202 & 306 & - & 4,1 & - & 591 & 20 & 135,2 \\
\hline Tardigrada & - & - & - & - & - & 0,3 & - & 37 & 1 & 5,2 \\
\hline Turbellaria & - & - & & - & - & 0,4 & - & 65 & - & - \\
\hline Всего & 100 & 100 & 589 & 17245 & 100 & 100 & 2273 & 14451 & 100 & 670,8 \\
\hline
\end{tabular}

Примечание: жирным шрифтом выделены доминанты и субдоминанты мейобентосных сообществ; * - средние значения по трем повторностям.

как в местах выхода газов субдоминантами были многощетинковые черви (Polychaeta) и одноклеточные Foraminifera. В мае 2016 г. в наиболее интенсивном сипе отмечено доминирование представителей мягкораковинных фораминифер отряда Allogromiida, а также нематод и гарпактикоид в качестве доминантов и субдоминантов на фоновых точках. В сентябре 2017 г. сообщества сиповых осадков были представлены инфузориями, а также гарпактикоидами и полихетами. Таким образом, в разные годы доминирование в сообществе мейофауны приходилось на различные таксоны.

Интересным индикатором степени потревоженности сообщества (уровень стрес- совости сообщества) может являться численность чувствительных к неблагоприятным факторам среды и устойчивых к ним таксономических групп мейобентоса. Свободноживущие морские нематоды - круглые черви - широко известны своей устойчивостью к самым различным стрессорам (гипоксии, высокой концентрации сероводорода, значительным колебаниям температуры и солености воды) (Platt, Warwick, 1983). Явное преобладание нематод как в сипе, так и в фоновых осадках отмечено только в сентябре 2004 г. Напротив, веслоногие ракообразные Copepoda, в том числе представители отряда Harpacticoida, достаточно чувствительная к органическому 
загрязнению группа животных (McLachlan, Brown, 2006). На фоновых точках в 2004 и 2016 гг. гарпактикоиды отмечены нами как субдоминирующая и доминирующая группы, что, как правило, служит показателем чистых незагрязненных осадков. В то же время доля гарпактикоидных копепод в микробиальных матах сипов за все время исследований была мала, оставаясь на уровне второстепенных или малочисленных таксономических групп, что может говорить о токсичности для них среды обитания в сипе. Морские тихоходки Tardigrada представлены видом Batillipes mirus Richters, 1909.

В сентябре 2014 г. мы изучили послойное распределение численности мейобентоса и его таксономическую структуру в местах интенсивных выходов газа (рис. 2). Наибольшая плотность поселений и вертикальные градиенты численности мейофауны приурочены к верхнему (0-3 см) слою микробного мата. В поверхностном слое мата в мейобентосном сообществе преобладали многощетинковые черви - полихеты. В слое 1-2 см в сообществе субдоминировали полихеты, морские клещи
Acarina и мягкораковинные фораминиферы Allogromiida, которые встречались во всех 0-5 см слоях грунта. Гарпактикоиды обнаружены только на глубине до 3 см микробиального мата (рис. 2).

Следует отметить, что на фоновых точках - песчаных полянах - характер вертикального распределения мейофауны в толще грунта заметно отличался от такового в микробном мате сипа. В верхнем слое 0-1 см грунта были обнаружены минимальные значения численности животных (1242 экз/0,01 м²), тогда как их основное скопление найдено в слое 3-4 см (12227 экз/0,01 м²). Глубже численность мейобентоса снижалась и в слое 4-5 см составляла лишь 8724 экз/0,01 м². Нематоды проникали вглубь песка на фоновой точке на большую глубину и в гораздо большем количестве. Гарпактикоиды, как и в сипе, не отмечены глубже 3 см грунта.

В целом, распределение животных внутри осадков метановых сипов соответствует классическим представлениям о распределении фауны в толщах илистых донных отложений (Мокиевский, 2009). Так, численность

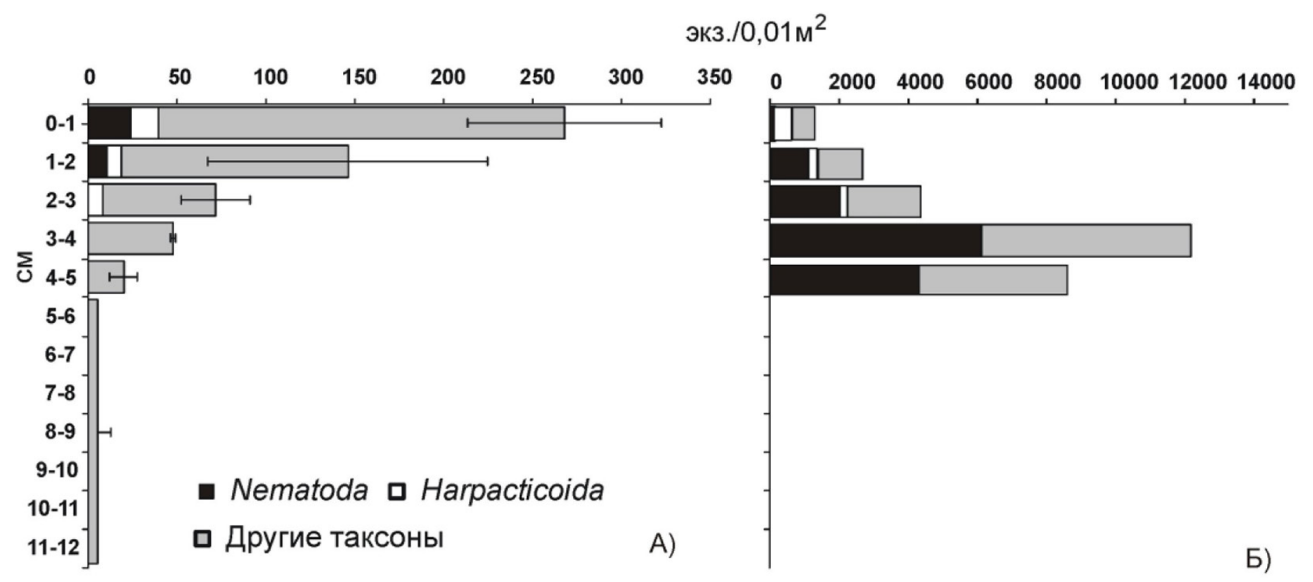

Рис. 2. Численность мейобентоса (экз/0,01 м²), его таксономическая структура и послойное распределение в колонке грунта в сентябре 2014 г.: А - сип (n=3, со стандартным отклонением); Б - фон

Fig. 2. The abundance of meiobenthos (ind./0.01 $\mathrm{m}^{2}$ ), its taxonomic structure and stratified distribution in the sediment cores in September 2014, A - seep ( $\mathrm{n}=3$, with standard deviation as error bars), 5 - reference point 
мейобентоса уменьшалась в глубине микробного мата, где, по данным (Орехова и др., 2013), производившим измерения в 2009 г. в месте нашего отбора проб, кислород присутствует только в поверхностных нескольких миллиметрах субстрата, а концентрация сероводорода достигает более 1500 мкМ/л уже в слое $0-1$ см.

Содержание органического вещества (ОВ) в сульфуреттах сипов значительно выше, чем на фоновых точках (табл. 1). В летний период 2009 г., т.е. в сезон наибольшей стагнации водных масс и максимальной активности микробных процессов, в бактериальных матах были обнаружены чрезвычайно высокие уровни содержания ОВ, превышающие аналогичные показатели на прилегающих фоновых станциях в 6,8 раз.

Среднее значение содержания ОВ в сипе в период 2004-2017 гг. нами определено как $256,24 \pm 30,01$ мг/г, тогда как в фоне $-39,78 \pm$ 8,94 мг/г (табл. 1). Органическое вещество в донных отложениях служит питательной средой для биоты, и, вероятно, его повышенное содержание в сипе является фактором, способным привлекать зообентос. Однако высокая концентрация токсичного сероводорода в сочетании с недостатком кислорода (и его отсутствием в более глубоких слоях осадка) ограничивает развитие макро- и мейофауны.

Таким образом, можно заключить, что в донных отложениях непосредственно у очагов газовыделений формируется своеобразный «экстремальный» биотоп с критическими условиями для существования биотыострой гипоксией (и даже аноксией в толще мата) и присутствием токсичного сероводорода. Вполне вероятно, высокая трофность микробиотопов газовых сипов - главная причина присутствия здесь зообентосных организмов, но лишь тех, которые адаптированы к гипоксии в совокупности с экстремально высокой концентрацией $\mathrm{H}_{2} \mathrm{~S}$.
Кроме того, в 2014 г. нами проводились наблюдения физиологического состояния мейобентоса из сиповых осадков методом прямого микроскопирования (Иванова, 2017). Было обнаружено, что живые подвижные мейобентосные животные в сипе обитали только в верхнем 0,5 см слое осадка и составляли около $3 \%$ от общей численности мейобентоса, находящегося в пробе. Можно предположить, что большинство животных, обнаруженных в пробах грунта из сипов, погибают в условиях отсутствия кислорода и отравления сероводородом. Логично допустить, что подвижный мейобентос стремится избегать таких экстремальных местообитаний.

Как уже отмечалось, в сентябре 2014 г. основные скопления мейобентоса обнаруживались в верхних 3 см осадков. Интересной особенностью фауны сипов оказалось то, что нематоды здесь практически отсутствовали, их единичные экземпляры обнаружены только в верхних 0-2 см осадка, в то время как, по литературным данным (Platt, Warwick, 1983), нематоды способны существовать в крайне неблагоприятных условиях среды и указаны как доминанты в глубоководных сиповых осадках Черного моря (Sergeeva, Gulin, 2007).

Нами также отмечено отсутствие гарпактикоид в бактериальном мате сипа в глубине осадка ниже 3 см, тогда как ранее регистрировали пики скопления гарпактикоид Darcythompsonia fairlensis T. Scott, 1899 (Copepoda: Harpacticoida) в слое 4-5 см микробного мата (Колесникова, Сергеева, 2011). К сожалению, указанными авторами не описана методика отбора проб осадков и невозможно однозначно заключить, шла ли речь о живых экземплярах либо это погибшие особи из поверхностных слоев, оказавшиеся в толще мата вследствие высокой скорости нарастания бактериального субстрата. 
Редокс-потенциал среды (Eh, мB) как интегральный показатель выражает соотношение окисленных и восстановленных форм, прежде всего, кислорода и сульфидов внутри донных осадков. Диаграмма рассеяния (scatter plot) значений численности мейобентоса (зафиксированных в сентябре 2014 г. для различных слоев грунта) и значений для этих же слоев осадка Еh показывает функциональную зависимость, выражающуюся в предпочтении мейофауной более окисленных поверхностных грунтов (рис. 3).

Наибольшие скопления мейобентоса в толще осадка соответствуют нормоксиче- ским условиям (при Еh около 0 мВ), минимальные численности инфауны наблюдаются в нижних слоях грунта при значениях Eh ниже - 280 мВ, указывающих на сильно восстановленную среду.

Для определения воздействия на кислородный режим водной толщи над полем сипов у побережья мыса Тарханкут в сентябре и ноябре 2009 г. были проведены измерения концентрации кислорода (табл. 4). Результаты вертикального зондирования показывают, что осадки сипа на глубине 3,5 м, образующие очаг сероводородного заражения, способны снижать концентрацию кислорода в

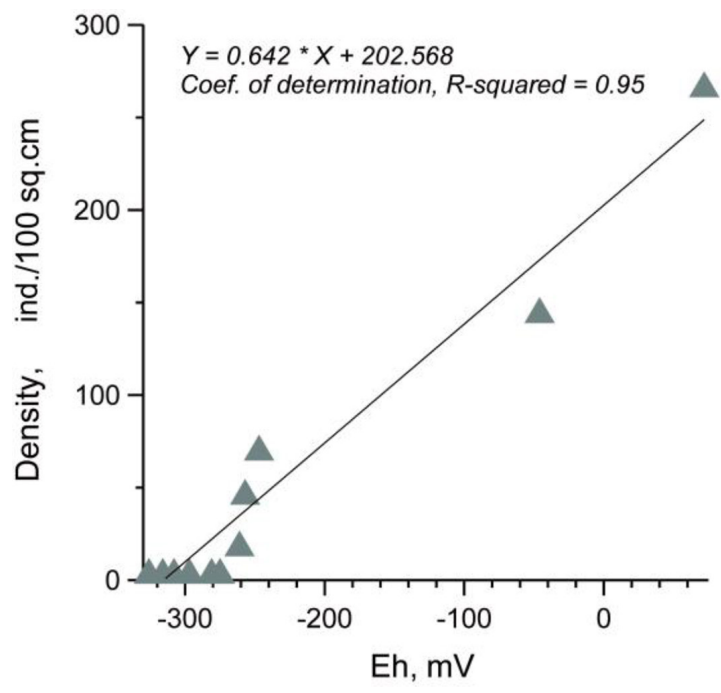

Рис. 3. Диаграмма рассеяния (scatter plot) общей численности мейофауны (экз/100 см²) vs. окислительновосстановительного потенциала (мВ) в сипе (сентябрь 2014 г.)

Fig. 3. Scatter plot of total meifauna density (ind./100 $\left.\mathrm{cm}^{2}\right) v s$. redox potential $(\mathrm{mV})$ in the seep sediments (September 2014)

Таблица 4. Концентрация кислорода $\mathrm{O}_{2}$ (мг/л) в водной толще над сипом, расположенным на глубине 3,5 м Table 4. Oxygen concentration $\mathrm{O}_{2}(\mathrm{mg} / \mathrm{L})$ in the water column above the seep, located at a depth of $3.5 \mathrm{~m}$

\begin{tabular}{c|c|c|c}
\hline Глубина, м & {$\left[\mathrm{O}_{2}\right]$ Сентябрь 2009 } & {$\left[\mathrm{O}_{2}\right]$ Ноябрь 2009 } & {$\left[\mathrm{O}_{2}\right]$ Сентябрь 2014 } \\
\hline 0,3 & 8,26 & 8,83 & 9,27 \\
1 & 8,18 & 8,77 & - \\
2 & 8,06 & 3,20 & - \\
3 & 7,43 & 2,71 & 7,72 \\
\hline
\end{tabular}


придонном слое воды на расстоянии не менее 1,5 м от дна.

В течение длительного периода наблюдений установлено, что после воздействия сильных штормов время восстановления экотопа тарханкутских сипов и, вероятно, бактериоценоза составляет один-полтора месяца. Можно предположить, что это важное свойство прибрежных местообитаний является одним из ключевых в динамике количественных показателей и состава донной фауны поля газовых сипов у мыса Тарханкут.

Таким образом, образующийся в результате микробиального окисления метана избыток органического вещества в грунте формирует специфическую донную среду. Повышенное содержание органики воздействует на бентосную фауну по-разному. С одной стороны, обогащенные органическим веществом донные осадки привлекательны для бентосных животных как источник пищи и могут стимулировать рост и разнообразие бентосных популяций (Austen, Widdicombe, 2006). С другой стороны, микробиальные процессы, связанные с разложением накопленного органического вещества, приводят к образованию больших концентраций сероводорода, токсичного для биоты, и критическому снижению кислорода в донной среде (Гулин и др., 2010). В результате взаимодействия ограничивающих и привлекающих факторов среды образуется так называемая зона экологического компромисса, в которой способны обитать лишь те представители донной фауны, которые обладают соответствующими биохимическими, физиологическими либо функциональными адаптациями.

В толще донных осадков с высоким содержанием органического вещества могут формироваться даже условия аноксии (Giere, 2009; Орехова и др., 2013) в глубоко лежащих слоях, куда не проникает обогащенная кис- лородом поровая морская вода. В этом случае с учетом того, что присутствие кислорода - первичная необходимость для дыхания донных гидробионтов-эукариот, насыщение грунтов органическим веществом, вероятно, способно оказывать губительный эффект для инфауны. Подобное явление «экологического компромисса» отмечалось нами ранее также для глубоководных мейобентосных сообществ Черного моря, ассоциированных с зонами газовыделений (Sergeeva, Gulin, 2007; Ivanova et al., 2012), и в газоносных осадках атлантической лагуны Риа Формоза (Южная Португалия) (Ivanova, 2014).

\section{Заключение}

Прибрежные метановые сипы формируют специфические условия среды морского дна, не оказывающие критического влияния на толщу покрывающих их вод, вместе с тем заметно изменяющие свойства донного грунта непосредственно в местах выхода газов. При этом некоторое снижение концентрации кислорода в водной толще непосредственно над сипом отмечено и в придонном слое толщиной до 1,5 м от дна.

Мейобентосные сообщества сипов находятся в угнетенном состоянии в сравнении с сообществами окружающих их донных субстратов, что отражается в снижении их численности. Пики плотности мейофауны сипов приурочены к верхнему 0-3 см слою микробного мата в отличие от окружающих песчаных грунтов, где гораздо более обильная мейофауна располагается глубже в слоях осадка. Доминирующими и субдоминирующими таксонами мейобентоса являются Nematoda, Foraminifera (Allogromiida) и Polychaeta.

Биотопы сипов характеризуются так называемой зоной «экологического компромисса» для бентосной биоты, образующейся в результате взаимодействия ограничивающих 
и привлекающих факторов среды, где обилие питательных органических веществ сочетается с присутствием критических для организмов концентрацией сероводорода и недостатком (либо полным отсутствием) кислорода. Так, например, в верхнем слое донных осадков формируется среда с крайне низкими величинами окислительно-восстановительного потенциала. ОВП в верхнем слое сульфуретт в непосредственной близости от выходов газов достигал -385 мВ, тогда как на прилегающих участках дна без газовыделений данный показатель имел положительные значения, типичные для шельфа Черного моря. Очевидно, что обитатели такого биотопа должны быть хорошо адаптированы к жизни в условиях токсического воздействия сероводорода, а также крайне острого дефицита кислорода.

Поскольку визуальные наблюдения, проведенные нами в пробах из сиповых отложений, показали, что только 3 \% от общей численности мейофауны проявляют признаки активной жизнедеятельности (Иванова, 2017), то вероятно, что значительная доля мейофауны, обнаруженной в сипах, - это погибшие особи из поверхностных слоев, оказавшиеся в толще мата вследствие высокой скорости нарастания бактериального субстрата, восстанавливающегося в промежутках между разрушительным воздействием сильным штормов.

В целом, респираторный режим и уровень трофности изученных экстремальных местообитаний служат в совокупности ключевыми факторами, определяющими экологическое состояние обитателей дна. Генеральным средообразующим фактором служит, вероятно, активность присутствующих в сипах сообществ метаногенных и метанотрофных микроорганизмов, формирующих экстремальные биоценозы, где сосуществуют про- и эукариотические организмы, энергетической базой которых является метан, а не солнечная радиация (Michaelis et al., 2002).

\section{Благодарности / Acknowledgements}

Исследование проведено по теме государственного задания ФГБУН ИМБИ «Функциональные, метаболические и токсикологические аспекты существования гидробионтов и их популяций в биотопах с различным физико-химическим режимом», номер государственной регистрации НИОКТР АААА-А18-118021490093-4, а также при поддержке гранта РФФИ № 1704-00023А. Авторы глубоко признательны Н.В. Пименову (ФИЦ Биотехнологии РАН, г. Москва) за плодотворное сотрудничество при проведении исследований, а также В.А. Тимофееву, В.П. Чекалову и И.Н. Аннинской (ИМБИ РАН, Севастополь) за помощь при проведении полевых и лабораторных работ.

The study was carried out to fulfil the state assignment to the A.O. Kovalevsky Institute of Biology of the Southern Seas of RAS on the subject "Functional, metabolic and toxicological aspects of the existence of aquatic organisms and their populations in biotopes with different physicochemical regimes", state registration number AAAA-A18-118021490093-4; it was also supported by the Russian Foundation for Basic Research, project no. 17-04-00023A. The authors are deeply grateful to N.V. Pimenov (Federal Research Center of Biotechnology RAS, Moscow) for fruitful cooperation in research, as well as V.A. Timofeev, V.P. Chekalov and I.N. Anninskaya (IMBI RAS, Sevastopol) for assistance in field and laboratory work. 


\section{Список литературы / References}

Гулин М.Б., Тимофеев В.А., Бондаренко Л.В. (2010) Зообентос в микробиотопах метановых сипов шельфовой зоны Крымского побережья. Системы контроля окружающей среды, 14: 225-229 [Gulin M.B., Timofeev V.A., Bondarenko L.V. (2010) Zoobenthos in the micro-biotopes of methane gas seeps within the Crimean coastal zone. Monitoring Systems of Environment [Systemy kontrolya okruzhayushchei sredy], 14: 225-229 (in Russian)]

Иванова Е.А. (2017) Экология мейобентоса метановых сипов Черного моря: фаунистические характеристики и результаты наблюдений физиологического состояния методом прямого микроскопирования. Экосистемы, 10: 28-34 [Ivanova E.A. (2017) Meiobenthos ecology within the methane seeps of the Black Sea: results of taxonomical study and direct microscopic. Ecosystems [Ekosistemy], 10: 28-34 (in Russian)]

Колесникова Е.А., Сергеева Н.Г. (2011) Первая находка вида Darcythompsonia fairlensis (T. Scott, 1899) (Copepoda, Harpacticoida) в Черном море. Морской экологический журнал, 10(1): 72 [Kolesnikova E.A., Sergeeva N.G. (2011) A new record of the species Darcythompsonia fairlensis (T. Scott, 1899) (Copepoda, Harpacticoida) from the Black Sea. Marine Ecological Journal [Morskoi Ekologicheskiy Zhurnal], 10(1): 72 (in Russian)]

Мокиевский В.О. (2009) Экология морского мейобентоса. М., Товарищество научных изданий КМК, 286 c. [Mokievsky V.O. (2009) Ecology of marine meiobenthos. Moscow, KMK Scientific Press, 286 p. (in Russian)]

Молисмология Черного моря (1992) Поликарпов Г.Г. (отв. ред.) Киев, Наукова думка, 304 с. [Black Sea molismology (1992) Polikarpov G.G. (ed.) Kiev, Naukova Dumka, 304 p. (in Russian)]

Орехова Н.А., Коновалов С.К., Овсяный Е.И. (2013) Изменение геохимических характеристик в донных осадках Крымского побережья. Экологическая безопасность прибрежной $и$ шельфовой зон и комплексное использование ресурсов шельфа. Сборник научных трудов. Вып. 27. Севастополь, НАН Украины, МГИ, ИГН, ОФ ИнБЮМ, с. 284-288 [Orekhova N.A., Konovalov S.K., Ovsjanyj E.I. (2013) Changes in geochemical characteristics in bottom sediments of the Crimean coast. Ecological safety of coastal and shelf zones and multiple use of shelf resources. Collected scientific papers. Issue 27. Sevastopol, National Academy of Science of Ukraine, Marine Hydrophysical Institute, Institute of Geological Science, Odessa Branch of Institute of Biology of the Southern Seas, p. 284-288 (in Russian)]

Сергеева Н.Г., Иванова Е.А., Лысых Н.М. (2006) Тихоходки (Tardigrada) прибрежной акватории Крыма (западный сектор Черного моря). Экология моря, 72: 57-64 [Sergeeva N.G., Ivanova E.A., Lysykh N.M. (2006) Bear animalcules (Tardigrada) from coastal region of Crimea (the western Black Sea). Marine Ecology [Ekologiya morya], 72: 57-64 (in Russian)]

Austen M.C., Widdicombe S. (2006) Comparison of the response of meio- and macrobenthos to disturbance and organic enrichment. Journal of Experimental Marine Biology and Ecology, 330(1): 96-104

Giere O. (2009) Meiobenthology - the microscopic motile fauna of aquatic sediments. Berlin, Heidelberg, Springer - Verlag, 527 p.

Gulin M.B. (2004) Dependence of location and intensity of the methane cold seeps on geophysical factors: the Black Sea near-shore shallow-water seeps, underwater video materials. Geophysical Research Abstracts, 6: 05394 
Hewitt E., Mudge S. (2004) Detecting anthropogenic stress in an ecosystem: 1. meiofauna in a sewage gradient. Environmental Forensics, 5(3): 155 - 170

Michaelis W., Seifert R., Nauhaus K., Treude T., Thiel V., Blumenberg M., Knittel K., Gieseke A., Peterknecht K., Pape T., Boetius A., Amann R., Jorgensen B.B., Widdel F., Peckmann J., Pimenov N.V., Gulin M.B. (2002) Microbial reefs in the Black Sea fueled by anaerobic oxidation of methane. Science, 297(5583): 1013-1015

Ivanova K., Gulin M., Timofeev V. (2012) Black Sea Holocene gas seeps as hot-spot environments with opposing natural properties: Zoobenthos high-activity and strong hypoxia coupled by H2S contamination sea. Effects of Climate Change on the World's Oceans: Materials of International Symposium (Yeosu, Korea, May 13-20 2012). p. 251

Ivanova K. (2014) Case study on Nematoda taxocenosis under variety of waste stress for four stations of Ria Formosa lagoon, Portugal. Marine Ecological Journal [Morskoi Ekologicheskiy Zhurnal], 13(4): 5-13

McLachlan A., Brown A.C. (2006) The ecology of sandy shores. Burlington, Academic Press, $373 \mathrm{p}$.

Platt H.M., Warwick R.M. (1983) Free-living marine nematodes. Part I. British Enoplids. Cambridge, Cambridge University Press, 278 p.

Sergeeva N.G., Gulin M.B. (2007) Meiobenthos from an active methane seepage area in the NW Black Sea. Marine Ecology, 28(1): 152-159

Sergeeva N.G., Gulin M.B., Ivanova E.A. (2005) Methane seeps and associated benthos fauna in the NW Black sea, data from METROL expeditions. Materials of VIII International Conference on Gas in Marine Sediments, Vigo - Spain, September 5-10, 6/9: 1-8

Skarke A., Ruppel C., Kodis M., Brothers D., Lobecker E. (2014) Widespread methane leakage from the sea floor on the northern US Atlantic margin. Nature Geoscience, 7(9): 657-661

Tarnovetskii I.Yu., Merkel A.Yu., Kanapatskiy T.A., Ivanova E.A., Gulin M.B., Toshchakov S., Pimenov N.V. (2018) Decoupling between sulfate reduction and the anaerobic oxidation of methane in the shallow methane seep of the Black Sea. FEMS Microbiology Letters, 365(21): fny235 